\title{
IX Walne Zebranie Stowarzyszenia Biblistów Polskich oraz 50. Sympozjum Biblistów Polskich (Warszawa, 18-20 września 2012)
}

18 września 2012 roku w gmachu Wyższego Metropolitalnego Seminarium Duchownego w Warszawie miało miejsce IX Walne Zebranie Stowarzyszenia Biblistów Polskich, a w dniach 19-20 września 2012 roku jubileuszowe 50. Sympozjum Biblistów Polskich.

Podczas IX Walnego Zebrania (18 września) przewodniczący Stowarzyszenia Biblistów Polskich ks. prof. Waldemar Chrostowski dokonał podsumowania i oceny ostatniego roku pracy stowarzyszenia. Wspomniano i modlono się za dwóch zmarłych członków stowarzyszenia: ks. dra Mariana Ejsmonta oraz ks. bpa prof. Jana Bernarda Szlagę. Zapowiedziano także zmianę władz stowarzyszenia na przyszły rok w związku z upływem kadencji.

W pierwszym dniu obrad 50. Sympozjum Biblistów Polskich (19 września) uroczystej koncelebrze mszy świętej przewodniczył ksiądz kardynał Kazimierz Nycz, arcybiskup metropolita warszawski, który wygłosił do zebranych homilię. Program wykładowy sympozjum składał się z referatów i komunikatów oraz dyskusji wokół nich. Z racji jubileuszu i okrągłej rocznicy sympozjum było poświęcone nie tyle zagadnieniom problemowym biblistyki, ile samej biblistyce, spojrzeniu wstecz na biblistykę polską, zwłaszcza ostatniego półwiecza. Chodziło o próbę dokonania bilansu dorobku naszej rodzimej biblistyki oraz wskazanie kierunków i perspektyw na przyszłość.

Referaty wygłosili: ks. prof. Waldemar Chrostowski, Pięćdziesiąt Sympozjów Biblistów Polskich - bilans i perspektywy, ks. prof. Henryk Witczyk, Wkład biblistów polskich w posoborowe studium Pisma Świętego, ks. prof. Antoni Tronina, Lubelska Szkoła Biblijna (1956-2006), dr hab. Krzysztof Mielcarek, Poszukiwania historycznego wymiaru osoby Jezusa i Jego Ewangelii w badaniach biblistów KUL, ks. dr Krzysztof Wons, Dom Słowa. 15-lecie Centrum Formacji Duchowej. 
Komunikaty wygłosili: ks. dr hab. Janusz Kręcidło MS, Wkład biblistów warszawskich, ks. dr Krzysztof Siwek, Wykłady z Pisma Świętego $w$ warszawskim seminarium duchownym $w$ dobie wielkich autorytetów biblistyki polskiej, ks. dr Stanisław Wronka, Wkład biblistów krakowskich, ks. dr hab. Janusz Nawrot, Wkład biblistów poznańskich, dr hab. Mieczysław Guzewicz, Świeccy bibliści w Polsce.

Na koniec ks. Adam Sekściński, redaktor portalu biblia.wiara.pl, przedstawił inicjatywę Akademii Biblijnej (o zasięgu ogólnopolskim) oraz Biblicum Śląskiego (o zasięgu lokalnym), czyli biblistykę w świecie nowych mediów (internet, wykłady mp3, radio, publikacje online).

W drugim dniu sympozjum (20 września), rozpoczętym mszą świętą pod przewodnictwem bpa Piotra Jareckiego, biskupa pomocniczego archidiecezji warszawskiej, który wygłosił także homilię, kontynuowano przegląd dorobku biblistyki polskiej na różnych polach jej działalności.

Referat wygłosił: ks. prof. Stefan Szymik, Nauka o natchnieniu i prawdzie Pisma Świętego Vaticanum II w recepcji biblistyki polskiej.

Komunikaty wygłosili: ks. dr hab. Dariusz Kotecki, Studium Pisma Świętego na Wydziale Teologicznym Uniwersytetu Mikołaja Kopernika w Toruniu (2001-2012), ks. dr Tomasz Kusz, Wkład biblistów (archi)diecezji katowickiej, dr Leszek Balkiewicz OFM, Franciszkański wkład w rozwój biblistyki polskiej, o. lic. Paweł Trzopek, Polscy bibliści w École Biblique et Archéologique Française w Jerozolimie - historia i perspektywy, ks. dr Cezary Korzec, Biblijna myśl Soboru Watykańskiego II w polskich czasopismach społeczno-religijnych lat 60. XX wieku.

Większość wystąpień miała charakter historyczny i podsumowujący dorobek biblistyki na danym polu czy w danym ośrodku naukowym. Pojawiały się znane nazwiska i inicjatywy, oceniano wkład i dorobek tak biblistów, jak i szkół i ośrodków biblijnych w Polsce. Nie zabrakło jednak zagadnień problemowych, ukazujących rozwój poszczególnych kwestii w biblistyce polskiej ostatnich dekad. Wszystkie wystąpienia ukażą się drukiem w specjalnym tomie. Niemało miejsca zajęły dyskusje po wystąpieniach, podejmujące historyczne i aktualne kwestie związane z biblistyką polską (np. niepublikowane szczegóły i ciekawostki z czasu powstawania pierwszych wydań Biblii Tysiąclecia czy wskazanie na ośrodki biblijne, których nie ujęto w referatach). Wręczono także księgi pamiątkowe: ks. prof. Janowi Łachowi oraz ks. prof. Józefowi Kozyrze. Sympozjum, jak każde takie spotkanie, miało wielką wartość integracyjną, do czego przyczyniły się spotkania towarzyskie, rozmowy w przerwach i przy posiłkach, a zwłaszcza spotkanie, które miało miejsce wieczorem po pierwszym dniu obrad w Pałacu Arcybiskupów Warszawskich, dokąd ks. kard. Kazimierz Nycz zaprosił biblistów na uroczystą kolację.

Następne, X Walne Zebranie SBP i 51. Sympozjum Biblistów Polskich mają się odbyć w dniach od 17 do 19 września 2013 roku w Toruniu.

Kraków

Marcin Majewski 